\title{
VALIDITAS DAN PRAKTIKALITAS MODUL UNTUK MATERI FUNGSI PEMBANGKIT PADA PERKULIAHAN MATEMATIKA DISKRIT DI STKIP PGRI SUMATERA BARAT
}

\author{
Yulyanti Harisman \\ Program Studi Pendidikan Matematika STKIP PGRI Sumatera Barat \\ Jln. Gunung Pangilun Padang, yulyyuki@gmail.com
}

\begin{abstract}
ABSTRAK
Masalah yang ditemukan pada perkuliahan Matematika Diskrit, mahasiswa hanya mengandalkan buku teks sebagai buku pegangan pada proses perkuliahan. Namun, buku teks tersebut masih sulit dipahami dan pemaparan materi masih terlalu luas dan sulit dipahami oleh mahasiswa yang berlatar belakang pendidikan SMU yang berbeda-beda oleh sebab itu diperlukan sebuah bahan ajar yang berupa modul yang dapat membatu siswa untuk mengkontruksi pikiran merekan dengan menggunankan pola pikir yang sederhana dan mudah dipahami mahasiswa Jenis penelitian ini adalah penelitian pengembangan. Penelitian ini menggunakan model 4-D yang terdiri dari 3 tahap yaitu: tahap pendefinisian (define) atau analisis kebutuhan, perancangan (design) dan pengembangan (develop). Modul divalidasi oleh pakar Matematika Diskrit. Praktikalitas diselidiki melalui observasi pelaksanaan perkuliahan dan wawancara dengan mahasiswa. Untuk efektifitas akan dilakukan pada penelitian selanjutnya.Analisis data dilakukan secara deskriptif dengan hasil validasi yaitu valid dari segi isi dan konstruk. Pada tahap praktikalitas, diperoleh hasil bahwa Modul pada perkuliahan Matematika Diskrit sudah praktis untuk digunakan. Dari hasil penelitian diperoleh bahwa Matematika Diskrit pada perkuliahan Matematika Diskrit yang dikembangkan telah valid, praktis digunakan sebagai bahan ajar untuk mahasiswa Program Studi Pendidikan Matematika STKIP PGRI Sumatera Barat
\end{abstract}

Kata Kunci: Modul, Matematika Diskrit, validitas, praktikalitas

\begin{abstract}
The problem found in Matemstic Diskrit lecturing was collec student just used one teks book. Eventhought it dificult for undestanding to collec student in STKIP PGRI Sumbar. because of that problem lecturer was needed modul to help student for contruck them idea whit simple and eazy for undarstanding to collec student. This research was a development reseach. An matematic discrit modul was developed using 4D model (Define, design, develop, and disseminate). The collection of data was conducted by validation and matematic diskrit modul testing. The research intrumets were validation sheets (to measure the validity of the product), questionnaires ( to see the motivation of the students), and observation sheets ( to observe the activities of the students). The data obtained were in the from of qualitative and quantitative data analyzed descriptively. The result of the research was in the form of an matematic diskrit for valid, practical. The result of thes reseach matematic diskrit modul was valid, practical.
\end{abstract}

Key Word: Modul, Diskrit Matematic, validations, praktikalitas

\section{Pendahuluan}

Matematika Diskrit merupakan salah satu matakuliah yang harus diambil oleh mahasiswa pendidikan matematika.
Mata kuliah ini merupakan Mata Kuliah Keahlian Berkarya(MKB) yang harus dipelajari dengan bobot 3 SKS oleh 
mahasiswa Program Studi Pendidikan Matematika STKIP PGRI SUMBAR. Mata kuliah ini merupakan mata kuliah yang penting dikuasai mahasiswa karena banyak dipakai dalam mempelajari mata kuliah lain. Pada mata kuliah matematika diskrit dipelajari Kombinatorik, Prinsip Sarang Merpati, kefisien binomial, Ekslusi-ingklusi, Fungsi Pembangkit, Relasi Rekursif dan Teori Graf. Pada dasarnya indikator pencapaian pembelajaran pada mata kuliah ini cukup menarik dan banyak aplikasinya dalam kehidupan sehari-hari.

Mengingat penting nya mata kuliah ini, sudah seharusnya perkuliahan pada perguruan tinggi khususnya pada mata kuliah Matematika Diskrit memberikan makna yang esensial, menarik serta materi yang diasajikan oleh dosen harus mudah dipahami oleh mahasiswa. Salah satu hal yang harus ada yang akan menjadikan perkuliahan mudah dipahami oleh mahasiswa adalah dosen harus memiliki bahan ajar yang mudah dipahami oleh mahasiswa. Bahan ajar hendaknya meransang mahasiswa untuk bisa memahami materi sendiri, materi tidak dijabarkan terlalu luas dan jauh dari silabus yang sudah disiapkan dalam satu sub pokok bahasan.

Berdasarkan wawancara yang dilakukan peneliti dengan dosen program studi pendidikan matematika STKIP
PGRI SUMBAR khususnya dosen yang mengajar Matematika Diskrit, diperoleh keterangan bahwa dalam perkuliahan selama ini mahasiswa mengalami kesulitan untuk memahami materi yang ada di dalam buku Matematika Diskrit. Hal ini disebabkan karena buku-buku Matematika Diskrit masih sulit dipahami oleh mahasiswa dan materi yang dijabarkan masih luas masih belum mencapai indikator materi yang ada pada silabus yang disiapkan oleh dosen. Bahan ajar yang dipakai hanya dari buku yang ada di perpustakaan saja, itupun jumlahnya terbatas. Hal lain yang menyebabkan mahasiswa sulit memahami buku paket adalah karena keterbatasan mahasiswa yang berasal dari asal jurusan yang berbeda-beda tidak hanya berasal dari jurusan IPA yang dapat dilihat pada Tabel 1.

Tabel 1. Asal Sekolah Menengah Mahasiswa Program Studi Pendidikan Matematika Tahun Ajaran 2009/2010$2010 / 2011$

\begin{tabular}{|c|c|c|c|c|c|c|}
\hline \multirow{5}{*}{$\begin{array}{c}\text { Tahun } \\
\text { Ajaran }\end{array}$} & \multicolumn{5}{|c|}{ Asal Sekolah } & \multirow{5}{*}{$\begin{array}{c}\text { Juml } \\
\text { ah }\end{array}$} \\
\hline & \multirow{2}{*}{\multicolumn{2}{|c|}{ SMA }} & \multirow{2}{*}{\multicolumn{2}{|c|}{$\begin{array}{l}\text { MAN/ } \\
\text { MAS }\end{array}$}} & $\mathrm{S}$ & \\
\hline & & & & & M & \\
\hline & IP & IPS & IP & IP & $\mathrm{K}$ & \\
\hline & A & & A & $\mathrm{S}$ & & \\
\hline $2009 / 2$ & 34 & 15 & 15 & 18 & 10 & 440 \\
\hline 010 & 7 & & 0 & & & \\
\hline 2010/2 & 20 & 8 & 10 & 5 & 12 & 332 \\
\hline 011 & 2 & & 5 & & & \\
\hline \multicolumn{7}{|c|}{ (Sumber: Bagian Administrasi Prodi) } \\
\hline $\mathrm{Pa}$ & $\mathrm{T}$ & 11 & terlil & at & hy & adanya \\
\hline
\end{tabular}


di sekolah menengah. Sehingga, mahasiswa harus mempunyai buku ajar yang menggunakan bahasa yang sederhana dan mudah dipahami oleh mahasiswa.

Berdasarkan realita yang terjadi dilapangan modul ini dikembangkan yang mudah dipahami oleh mahasiswa dan sesuai dengan kopetensi dasar pada silabus. Modul ini hanya dikembangkan pada satu modul dengan tiga kali pertemuan pada Sub Materi Fungsi Pembankit, sehingga judul dari penelitian ini adalah "Pengembangan Modul Untuk Materi Fungsi Pembangkit Pada Perkuliahan Matematika Diskrit di STKIP PGRI Sumatera Barat”.

\section{Metode Penelitian}

\section{Jenis penelitian}

Model pengembangan adalah seperangkat prosedur yang berurutan untuk melaksanakan perancangan dan pengembangan yang diwujudkan dalam bentuk grafis (diagram) atau naratif. Prosedur pengembangan model ini menggunakan model 4-D yang dikemukakan oleh Thiagarajan dkk dalam Trianto (2011: 189). Model ini terdiri dari 4 tahap, yaitu 1) pendefinisian (define), 2) perancangan (design), 3) pengembangan (develop), dan 4) penyebaran (dessiminate). Pada penelitian ini hanya dilakukan 3 tahap, yaitu tahap pendefinisian, tahap perancangan dan tahap pengembangan. Tahap keempat yaitu tahap penyebaran tidak dilakukan karena memerlukan waktu yang panjang dan jumlah Perguruan Tinggi sampel yang banyak.

\section{Prosedur Pengembangan}

Penelitian ini bertujuan untuk mengembangkan Modul Matematika Diskrit yang valid, praktis, dan efektif dari segi isi dan konstruk. Rancangan penelitian selengkapnya dapat diuraikan pada prosedur berikut ini.

\section{Tahap Pendefinisian (define)}

Tahap ini dilakukan guna melihat gambaran kondisi di lapangan yang berkaitan dengan proses belajar mengajar Matematika Diskrit di STKIP PGRI Sumatera Barat, kemudian menganalisis permasalahan. Proses yang dilakukan adalah sebagai berikut.

a. Analisis silabus yang bertujuan untuk mengetahui apakah materi yang diajarkan sudah sesuai dengan standar kompetensi dan kompetensi dasar mata kuliah.

b. Analisis buku-buku teks Matematika Diskrit, untuk melihat kesesuaian isi buku dengan standar kompetensi dan kompetensi dasar yang harus dicapai mahasiswa. Buku-buku yang telah sesuai akan digunakan sebagai acuan 
penyusunan konsep, contoh soal dan latihan pada Modul yang akan dikembangkan.

c. Analisis literatur yang terkait dengan pengembangan Modul

d. Analisis karakteristik mahasiswa untuk memudahkan menyusun tingkat bahasa dalam Modul dan kesukaran soal.

e. Wawancara dengan teman sejawat dan mahasiswa yang bertujuan untuk mengetahui masalah/hambatan apa saja yang dihadapi di lapangan sehubungan dengan perkuliahan Modul.

2. Perancangan (design)

Hasil dari tahap pendefinisian digunakan pada tahap perancangan. Pada tahap ini, tindakan yang akan dilakukan adalah merancang Modul Matematika Diskrit. Modul ini terdiri dari tiga Kegiatan Belajar. Bagianbagiannya yaitu: Kegiatan Belajar 1 mengenai Fungsi Pembangkit Biasa dan Fungsi Pembangkit Eksponensial, Kegiatan Belajar 2 mengenai Aplikasi Fungsi Pembangkit Biasa dan Fungsi Pembangkit Eksponensial dan Kegiatan Belajar 3 mengenai Fungsi Pembangkit Biasa dan Fungsi Pembangkit Eksponensial

Setiap modul terdiri atas beberapa kegiatan belajar. Setiap kegiatan belajar memuat materi, contoh, latihan terbimbing, latihan mandiri, umpan balik, dan tindak lanjut

3. Pengembangan (develop)

Pada tahap ini tindakan yang dilakukan adalah memvalidasi, menguji praktikalitas dan efektifitas Modul

a. Tahap validasi

Ada 2 macam validasi yang digunakan pada Modul ini, yaitu sebagai berikut :

1) Validitas isi, yaitu apakah Modul telah dirancang sesuai dengan silabus mata kuliah.

2) Validitas konstruk, yaitu kesesuaian komponenkomponen Modul dengan indikator-indikator yang telah ditetapkan.

Modul yang sudah dirancang, dikonsultasikan dan didiskusikan dengan pakar materi Matematika Diskrit, pakar Teknologi Pendidikan dan pakar bahasa. Saran dari para pakar digunakan untuk menyempurnakan Modul. Kegiatan validasi dilakukan dalam bentuk mengisi lembar validasi Modul dan diskusi sampai diperoleh Modul yang valid dan layak untuk digunakan. Adapun aspek-aspek yang divalidasi dapat dilihat pada tabel berikut. 
Tabel 2. Validasi Modul

\begin{tabular}{|c|c|c|c|}
\hline $\begin{array}{c}\mathbf{N} \\
\mathbf{0}\end{array}$ & Aspek & $\begin{array}{c}\text { Metode } \\
\text { Pengumpula } \\
\text { n Data }\end{array}$ & $\begin{array}{c}\text { Instrume } \\
n\end{array}$ \\
\hline 1. & $\begin{array}{l}\text { Materi } \\
\text { dalam } \\
\text { Modul }\end{array}$ & $\begin{array}{l}\text { Memberikan } \\
\text { lembar } \\
\text { validasi }\end{array}$ & $\begin{array}{l}\text { Lembar } \\
\text { validasi }\end{array}$ \\
\hline 2. & Penyajian & kepada pakar & \\
\hline 3. & $\begin{array}{l}\text { Bahasa dan } \\
\text { keterbacaa } \\
n\end{array}$ & $\begin{array}{l}\text { Matematika } \\
\text { Diskrit, } \\
\text { pakar } \\
\text { teknologi } \\
\text { pendidikan } \\
\text { dan pakar } \\
\text { bahasa }\end{array}$ & \\
\hline
\end{tabular}

b. Tahap Praktikalitas

Praktikalitas merupakan tingkat keterpakaian Modul oleh mahasiswa dan dosen, dengan melakukan uji coba menggunakan Modul yang telah direvisi. Uji coba terbatas dilakukan pada satu lokal Program Pendidikan Matematika STKIP PGRI Sumatera Barat tahun ajaran 2012/2013. Adapun aspek-aspek praktikalitas Modul dapat dilihat pada Tabel 3

Tabel 3. Praktikalitas Modul

\begin{tabular}{lll}
\hline \multicolumn{1}{c}{$\begin{array}{c}\text { Aspek yang } \\
\text { dinilai }\end{array}$} & $\begin{array}{c}\text { Metode } \\
\text { pengumpul } \\
\text { an data }\end{array}$ & $\begin{array}{c}\text { Instrume } \\
\text { n }\end{array}$ \\
\hline $\begin{array}{l}\text { Pelaksanaan } \\
\text { perkuliahan } \\
\text { dengan }\end{array}$ & $\begin{array}{l}\text { Observasi } \\
\text { pelaksanaan } \\
\text { perkuliahan }\end{array}$ & $\begin{array}{l}\text { Lembar } \\
\text { observas } \\
\text { i }\end{array}$ \\
modul & & \\
$\begin{array}{l}\text { Waktu yang } \\
\text { dibutuhkan }\end{array}$ & Wawancara & Pedoman \\
mahasiswa dalam & mahasiswa & $\begin{array}{l}\text { wawanca } \\
\text { mempelajari }\end{array}$ \\
Modul & & \\
Kemudahan dalam & & \\
penggunaan & & \\
Modul & & \\
Manfaat & & \\
mempelajari & & \\
Modul & & \\
\hline
\end{tabular}

Modul tersebut dikatakan praktis

jika pengguna tidak kesulitan memahami materi yang disajikan, mudah pemeriksaannya serta lengkap dengan petunjuk yang jelas. Jika hasil belum praktis, dilakukan perbaikan dan hasil perbaikan harus divalidasi terlebih dahulu. Setelah hasil perbaikan dinyatakan valid, dilakukan uji praktikabilitas terhadap perbaikan. Ini dilakukan sampai ditemukan Modul yang praktis.

\section{Instrument yang digunakan}

Untuk melihat validitas modul digunakan lembar validasi sedangkan untuk melihat praktikalitas modul digunakan lebar wawancara.

\section{Hasil dan Pembahasan}

\section{Validitas Modul}

Hasil validasi menunjukkan bahwa validitas Modul untuk perkuliahan Matematika Diskrit pada mahasiswa Program Studi Pendidikan Matematika STKIP PGRI Sumatera termasuk dalam kriteria valid. Ini berarti, Modul yang dikembangkan dapat mengukur apa yang seharusnya diukur dengan tepat. Hal ini senada dengan pendapat Djaali (2004: 65) yang menyatakan bahwa suatu instrumen dikatakan valid jika instrumen tersebut dapat digunakan untuk mengukur apa yang seharusnya diukur.

Modul pada perkuliahan Matematika Diskritsudah valid berdasarkan hasil penilaian dari validator. 
Materi yang disajikan telah sesuai dengan kompetensi yang ingin dicapai. Materi telah disajikan dengan urutan yang sistematis sehingga mampu memfasilitasi mahasiswa untuk belajar mandiri. Materi yang disajikan pada Modul telah memberikan kesempatan kepada mahasiswa untuk menemukan sendiri konsep-konsep dari materi yang dipelajarinya.

Konsep-konsep yang diuraikan pada materi dipertegas dengan grafik, tabel atau gambar. Hal ini terbukti mampu meningkatkan pemahaman mahasiswa terhadap konsep yang dipelajarinya. Selain itu, contoh soal, latihan dan latihan mandiri relevan dengan materi yang disajikan sehingga mahasiswa tidak menemukan kendala yang berarti dalam memahami dan menyusun penyelesaiannya.

Kompetensi utama dan pendukung telah disajikan secara jelas sehingga mahasiswa dapat mengetahui kompetensi apa saja yang harus dicapai selama perkuliahan. Petunjuk penggunaan Modul dapat dipedomani dengan baik oleh mahasiswa sehingga pada saat perkuliahan tidak ditemukan kendala yang berarti seputar cara penggunaan modul dalam pembelajaran. Secara visual, penulisan konsep, ide, istilah dan rumus yang ada pada Modul telah disajikan secara jelas. Hal ini terbukti dari tidak adanya pertanyaan mahasiswa seputar penulisan pada Modul.

$\begin{array}{ccc}\text { Penyajian } & \text { materi telah } \\ \text { membahasakan gagasan yang ingin }\end{array}$ dicapai sehingga mahasiswa tidak kesulitan dalam menangkap maksud yang ingin disampaikan. Penyajian materi juga telah memunculkan proses pembentukan dan pemahaman konsep karena disajikan ke dalam tahapan yang jelas dan terurut. Selain itu, Penyajian materi telah melibatkan mahasiswa secara aktif menemukan konsep secara mandiri. Gambar disajikan secara jelas dengan warna yang bervariasi sehingga dapat membantu mahasiswa dalam memahami konsep yang dipelajarinya. Modul telah menyajikan perumusan masalah yang akan menjadi fokus bagi mahasiswa dalam melakukan penemuan-penemuan.

Kalimat yang digunakan telah sesuai dengan kaidah bahasa Indonesia. Kalimat yang digunakan juga telah melibatkan kemampuan berfikir logis mahasiswa. Struktur kalimat telah sesuai dengan tingkat pemahaman mahasiswa. Bentuk dan ukuran huruf pada Modul telah sesuai dengan kapasitas keterbacaan mahasiswa. Selain itu, kalimat yang digunakan dalam penyajian Modul tidak memberikan makna ganda (ambigu). 


\section{Praktikalitas Modul}

Untuk menjawab "Bagaimana praktikalitas modul pada Mata kuliah Matematika diskrit?" telah dilakukan observasi mengenai pelaksanaan perkuliahan dan wawancara dengan mahasiswa sehingga diperoleh kesimpulan bahwa Modul untuk perkuliahan Matematika Diskrit sudah praktis. Indikator dari praktikalitas adalah pelaksanaan perkuliahan, waktu, penggunaan dan manfaat.

a. Pelaksanaan perkuliahan dengan Modul sudah sesuai rencana

Penggunaan Modultidak mendapatkan kendala yang berarti, dengan arti lain situasi berjalan dengan normal sesuai dengan rencana yang telah dirumuskan di dalam SAP (dapat dilihat pada Lampiran 3). Meskipun ada beberapa mahasiswa yang masih belum memahami materi dengan bagus

b. Waktu yang diberikan cukup

Pamakaian Modul lebih efisien terhadap waktu terkait dengan tidak perlunya mahasiswa mencatat penjelasan dari dosen karena modul telah dilengkapi dengan uraian materi yang lengkap. Secara umum kendala yang ditemukan ketika pelaksanaan perkuliahan adalah waktu yang disediakan untuk menemukan konsep dan mengerjakan soal sudah cukup. Hal ini disebabkan karena modul sudah menggunakan penurunan rumus yang sederhana dan mudah dimengerti mahasiswa

c. Penggunaan Modul memberikan kemudahan bagi mahasiswa

Penggunaan Modul dapat memudahkan mahasiswa dalam memahami materi karena penyajian materi dan pembahasan contoh soal mudah dimengerti. Oleh karena itu, dalam proses perkuliahan mahasiswa tidak banyak membutuhkan bimbingan dosen.

d. Modul sangat bermanfaat bagi mahasiswa

Manfaat yang dirasakan terhadap proses perkuliahan dengan menggunakan Modul adalah meningkatnya aktivitas belajar mahasiswa dan kemandirian dalam belajar.

\section{Kesimpulan}

Modul dikembangkan melalui tahap pendefinisian (define), tahap perancangan (design) dan tahap pengembangan (develop). Berdasarkan hasil penelitian, diperoleh kesimpulan sebagai berikut.

1. Modul pada perkuliahan Matematika Diskrit memiliki validitas yang sangat valid baik dari aspek materi, penyajian, bahasa dan keterbacaan.

2. Berdasarkan penilaian melalui observasi pada pelaksanaan perkuliahan dan hasil wawancara 
diketahui bahwa Modul pada perkuliahan Matematika Diskrit sudah praktis dan mudah digunakan oleh mahasiswa.

\section{Ucapan Terimakasih}

Terimakasih kepada

1. Ketua Prodi Pendidikan Matematika

2. Teman Sejawat

\section{Pustaka}

Muliyardi. 2006. Pengembangan Model Pembelajaran Matematika dengan Menggunakan Komik di Kelas I Sekolah Dasar. Disertasi tidak diterbitkan. Surabaya : Pasca Sarjana UNESA.

Nasution. 2008. Berbagai Pendekatan Dalam Proses Belajar Mengajar. Jakarta: PT Bumi Aksara

Sanjaya, Wina. 2006. Strategi Pembelajaran Berorientasi Standar Proses Pendidikan. Jakarta: Prenada Media

Sudijono, Anas. 2005. Pengantar Statistik Pendidikan. Jakarta: RajaGrafindo Persada.

Kuantitatif, Kualitatif, dan $R \& D$. Bandung: Alfabeta 